\title{
THE EU AIR TRANSPORT LIBERALIZATION AND RE-REGULATION
}

\author{
Francesco Gaspari ${ }^{*}$
}

\author{
Studio Legale Pierallini \& Associati, Rome, Italy \\ email: fran.gaspari@libero.it
}

GASPARI, Francesco. The EU Air Transport Liberalization and Re-regulation. International and Comparative Law Review, 2011, Vol. 11., No. 2, pp. 7-42. DOI: 10.1515/iclr-2016-0102.

\begin{abstract}
Over the last decades, international air transport liberalization has steadily evolved. As a consequence, many initiatives all over the world have paved the way to enhance international air transport liberalization, and numerous models have been hypothesized for a new multilateral aviation regime to supplant bilateralism, which however, remains the primary vehicle for liberalizing international air transport services for most States. The present study aims at investigating the EU experience in the field of liberalization and re-regulation of air transport, taking into account the other approaches developed internationally, where relevant. The paper is divided into four sections. After having introduced, in the first section, the different forms and venues of liberalization and regulation of international air transport, the process of Community liberalizations is analyzed, taking into account, on one side, the most recent air transport agreements in this field between the EU and third countries and, on the other side, the actual and potential benefits and drawbacks stemming from the implementation of these liberalization policies, which are still ongoing. In the last part of the paper, a new legal order in international air transport - stemming from the recent liberalization and re-regulation policies in the "Old Continent" - will be identified. In order to overcome the political and legal issues brought about by the liberalization and re-regulation of air transport worldwide, the paper concludes that stronger cooperation between international and regional actors must be implemented, and a global approach within a specialized international organization should be enhanced.
\end{abstract}

Keywords: EU Law, national courts, national procedural rules, interim measures 


\section{The regulation of international air transport: From bilateralism to regi- onalism.}

\subsection{The Chicago Convention.}

International air transport has always been one of the most regulated of industries. ${ }^{1}$ Traditionally, it has been regulated on the basis of the Chicago Convention ${ }^{2}$, which most countries in the world (including all EU Member States) have ratified. ${ }^{3}$

The Chicago Convention of 1944 was based on international bilateral air service agreements ${ }^{4}$, by which nations could trade the freedom of the skies among themselves. As a result, thousands of bilateral agreements were stipulated among States, and these agreements decided which airlines could fly between them, the capacity of each airline, the fares to be charged, as well as other clauses. ${ }^{5}$

1.2 Globalization, liberalization, and re-regulation: The new legal order of international air transport.

This regulatory system has been changing recently because of worldwide initiatives that have paved the way for enhancing air transport liberalization ${ }^{6}$. This

* Francesco Gaspari - Ph.D. in Law (Civil Law and Constitutional Legality),School of Advanced Studies (SAS), University of Camerino (Italy). Research Fellow, McGill Institute of Air and Space Law (IASL), Montreal. Research Fellow, Development of European Mediterranean Transportation (Demetra) Research Center, Rome. Attorney at Law - Member of the Italian Bar. Associate, Studio Legale Pierallini \& Associati, Rome.

1 K. Button, The impact of US-EU "Open Skies" agreement on airline market structures and airline networks, 15 Journal of Air Transport Management, 59, 59-60 (2009); W. Hubner and P. Sauvé, Liberalization scenarios for international air transport, 35 Journal of World Trade, 973, 973 (2001); L. E. Gesell and P.S. Dempsey, Air Transportation: Foundations for the $21^{\text {st }}$ Century, Chandler, Coast Aire Publications, 373 (2005), who state that in the US, despite the Airline Deregulation Act, the air transport sector has never been "deregulated", and "today the airlines are the most regulated industry on earth". Moreover, regulation "has been around for a long time and will not likely be going away in the foreseeable future".

2 Convention on International Civil Aviation of 7 December 1944.

3 L. Ortiz Blanco and B. Van Houtte, EC Competition Law in the Transport Sector, Oxford, at 164 (1996); B. F. Havel, Beyond Open Skies. A New Regime for International Aviation, Alphen aan den Rijn, 10, 417, and passim (2009); A. Kotaite, Legal aspects of the international regulation of civil aviation, XX Annals of Air and Space Law, 9, 12 (1995); K.-H. Böckstiegel, Current challenges in the legal regulation of civil aviation, XX Annals of Air and Space Law, 135, 135 (1995); A. Masutti, Il diritto aeronautico. Lezioni, casi e materiali, Torino, at $29 \mathrm{ff}$. (2009).

4 WTO, Communication from the International Civil Aviation Organization, S/C/W/63, at paragraph II.2 (October 23, 1998). On bilateral air service agreements is still today of fundamental importance the Elda Turco Bulgherini's book, La disciplina giuridica degli accordi aerei bilaterali, Padova, 1984 (and sources cited therein).

5 The bilateral air transport system applies not only to passenger transport, but also to air cargo.

6 H.W. Bashor, A New Legal Order in Air Transport, 2 Journal of Diplomatic Language, 1 (June 2005); Gesell and Dempsey, supra note 1, at 402; P.S. Dempsey and L.E. Gesell, Airline Management: Strategies for the 21 $1^{\text {st }}$ Century, Coast Aire, Chandler, 441 (1997); ICAO,

\section{(c) Palacký University Olomouc, Czech Republic, 2011. \\ ISSN 1213-8770 (print), ISSN: 2464-6601 (online).}


is why numerous models have been hypothesized for a new (multilateral) aviation order to supersede bilateralism ${ }^{7}$, which still remains the primary vehicle for liberalizing international air transport services for most States. ${ }^{8}$

Those models have to take into account the globalization process of the airline industry that is already under way. ${ }^{9}$ In light of this process, "[g] overnment intrusion should be restricted to competition law discipline," and government intervention should be limited (only) to ensure, on the basis of objective criteria, public service obligation concerning links with isolated destinations. ${ }^{10}$

The liberalization of air transport has entailed another phenomenon that is connected and consequent to that process: the re-regulation of air transport. As pointed out by some authors, air transport liberalization never represents complete deregulation because it brings about a re-regulation of the sector under other political and legal systems that are based on, for example, the application of antitrust rules, which are considered a form of governmental intervention. ${ }^{11}$ The public intervention, in terms of applicable regulation in the field of air transport, may take different forms, related, inter alia, to security regulations defined multilaterally by ICAO.

Economic Commission, Developments in International Air Transport Regulation and Liberalization, A37-WP/5 EC/1, Presented by the Council of ICAO to the ICAO Assembly's $3^{\text {th }}$ Session, at paragraph 3.4 (June 18, 2010); ICAO, Regulatory and Industry Overview, Information Paper, at paragraph 1.1 (August 15, 2006); WTO, supra note 4, at paragraph 2; D. Kreymborg, Developments relevant to international air transport in the World Trade Organization (WTO). Analysis of the First Review of the GATS Annex, 28 Annals of Air and Space Law, 473 (2003).

7 Havel, supra note 3, at 524. See also Bashor, supra note 6, at 1-2; S. Morris, Competition in air transport in Europe under a World Trade Organization (WTO) umbrella, XXXII Annals of Air and Space Law, 536 (2007); Hubner and Sauvé, supra note 1, at 976; M. Geloso Grosso, The political economy of liberalizing air transport in APEC: Regulatory aspects and negotiating options, GEM Working Paper, at 2 (June 2010), on line http://www.gem.sciences-po.fr/content/publications/pdf/GelosoGrosso_political_economy_airTransportLiberalisation062010.pdf.

8 ICAO, Overview of trends and developments in international air transport, ICAO Secretariat, paragraph 2.2 (March 24, 2009). See also ICAO, Liberalization Developments Related to Market Access, presented by the Secretariat at the Worldwide Air Transport Conference: Challenges and Opportunity of Liberalization, ATConf/5-WP/21, paragraph 2.2 (March 3, 2003); ICAO, Manual on the Regulation of International Air Transport, Montreal, at 2.3-1 (2004). More recently, see M. Polkowska, The Review of some Aspects of State Sovereignty in the Airspace, in The Aviation \& Space Journal, January/March 2011, No. 1, 12, 16.

9 I. Lelieur, Law and Policy of Substantial Ownership and Effective Control of Airlines. Prospects for Change, Aldershot, at 129 (2003), who argues that the globalization process demands "the choice of which markets to enter, and how to compete efficiently in those markets, should ultimately be the province of individual carrier managements".

10 Havel, supra note 3, at 524 .

11 See R. Bork, The Antitrust Paradox, New York, 1978. 
This new legal order in the field of air transport is being developed at different levels: at regional, multilateral ${ }^{12}$, plurilateral $^{13}$, bilateral ${ }^{14}$, and national. ${ }^{15}$ Moreover, the industry has recently undertaken initiatives in promoting liberalization. ${ }^{16}$

12 ICAO represents one of the most important example of World-Wide multilateralism in the field of aviation. Other global multilateralism organizations in the field of air transport are, inter alia, WTO (World Trade Organization), OECD (Organization for Economic Cooperation and Development) and UNCTAD (United Nation Conference on Trade and Development).

13 See, for example, the Multilateral Agreement on the Liberalization of International Air Transportation (MALIAT), known as the 'KONA' open skies agreement, which was signed in 2001 by five like-minded Members of the Asia-Pacific Economic Cooperation (APEC), namely Brunei, Chile, New Zealand, Singapore and the United States.

14 As concerns bilateral approaches, it is well known that bilateral regulation of international air transport is formed by agreements, understandings or arrangements between two states. As opposed to both national and multilateral regulation, bilateral regulation involves no permanent institutions or organizations: see ICAO, Manual, supra note 8, at $2.2-1$.

15 Initiatives at national level have been undertaken recently: see, for instance, the new international air policy announced by the Government of Canada called "Blue Sky" in 2006, concerning air service negotiations, and envisaging a change from the previous gradual reduction of restrictions of bilateral air services agreements to "open skies" agreements. Other initiatives have been undertaken with regard to market access for foreign airlines by Bahrain, Cambodia, Chile, China, Ecuador, Guatemala, Honduras, India, Kuwait, Lebanon, Morocco, Pakistan, Philippines, Sri Lanka, Tunisia, the United Arab Emirates, Japan; as for airline pricing, by the United Kingdom Civil Aviation Authority; as for designation of airlines, by Bangladesh, India, Kuwait and Nigeria, while, in the field of domestic air transport, Brazil, China, India, Japan, Indonesia, Mozambique, Saudi Arabia and Thailand have been fostering liberalization measures: see ICAO, Overview, supra note 8, at paragraph 2.17 .

16 In particular, in 2004, the International Air Transport Association (IATA) developed a Study on ownership and control liberalization. See IATA, Advancing the Liberalization of Ownership and Control, Paper presented to the ICAO Assembly's 35th Session, A35-WP/64 (July 8, 2004). Furthermore, 14 governments and the European Commission were invited by the same international Association to an "Agenda for Freedom Summit" in October 2008, with the goal to discuss how to further liberalize market access and airline ownership and control rules. A second Summit was held in November 2009, when seven governments and the European Union signed a common policy statement on liberalizing market access, pricing and ownership. See ICAO, A37-WP/5 EC/1, supra note 6, at paragraph 3.5. 
1.3 Regional experiences in liberalizing air transport: An overview. Multilateralism and regionalism concepts. Purpose of the study.

As far as regional levels are concerned, many initiatives toward liberalization have been undertaken in their relevant areas. Before the 1994 ICAO Fourth Worldwide Air Transport Conference ${ }^{17}$ there were just two regional agreements, namely the Single Aviation Market in the European Union (1987) and the Decision of Integration of Air Transport amongst five Andean Pact States (Andean "Open Skies" Policy) in 1991. ${ }^{18}$

Since 1995, a considerable number of regional groups have been developed, and numerous regional arrangements have emerged. Currently, many agreements or arrangements for the liberalization of intra-regional air transport services are in operation, such as the Single Aviation Market within the European Union established in 1987 amongst the Member States (today, 27 States); the Decision of Integration of Air Transport of the Andean Community (CAN, then Andean Pact) amongst four States in 1991; the Multilateral Air Service Agreement (MASA) of the Caribbean Community (CARICOM) in 1998 amongst 15 States in the Caribbean, which entered into force in 1999 for nine States; the Agreement on Sub-regional Air Services (Fortaleza Agreement) of the Southern Common Market of 1999 amongst six MERCOSUR States (in South America); the Banjul Accord for an Accelerated Implementation of the Yamoussoukro Declaration of 1997 amongst six States; the Multilateral Air Service Agreement for the Banjul Accord Group of 2004 amongst seven States; the Agreement on the Establishment of Sub-Regional Air Transport Cooperation amongst Cambodia, Lao People's Democratic Republic, Myanmar, and Viet Nam of 1998 (CLMV) (but a formal multilateral Agreement was signed in 2003); and the Agreement on the Liberalization of Air Transport of the Arab League States of 2007 amongst six States.

The 2007 Agreement enacted the Intra-Arab Freedoms of the Air Programme, which dates back to 2000, amongst 16 States of the Arab Civil Aviation Commission (ACAC) in the Middle East and Northern Africa; the Agreement on Air Transport signed in 1999 amongst the six States of the Economic and Monetary Community of Central Africa (CEMAC); the regulations for the implementation of Liberalization of Air Transport Services of the Common Market for Eastern and Southern Africa (COMESA) of 1999 amongst 12 States; the Yamoussoukro II Ministerial Decision amongst 52 African Union States, signed in 1999 and entered into force in 2000; the Pacific Islands Air Services Agreement (PIASA) of the Pacific Island Forum, which was signed in 2007 amongst six States; the Air Transport Agreement of the Association of Caribbean States (ACS), signed in 2008 amongst seven States; the ASEAN Multilateral Agreement on the Full Liberalization of Air Freight Services, signed in Manila on May 20, 2009. ${ }^{19}$ Fur-

17 ICAO Worldwide Air Transport Conference ATConf/4, 1994.

18 See ICAO, Regulatory and Industry Overview, supra note 6, at paragraph 2.4.

19 ICAO, Overview, supra note 8, at paragraph 2.5. 
ther liberalization initiatives have been undertaken by the ten Member States of ASEAN, which adopted a Multilateral Agreement on Air Services.

Other regional arrangements are in the process of formal signature or ratification, such as the Common Air Transport Programme amongst eight Member States of the Economic and Monetary Union of West Africa (WAEMU) of 2002. ${ }^{20}$ Another important regional forum is the Asia-Pacific Economic Cooperation (APEC), which has developed liberalization initiatives since 1995.

Within regional initiatives, the EU experience represents, as we will clearly see below, the most prominent example of regional liberalization in the field of air transport.

The present study aims at investigating the EU experience in the field of liberalization and re-regulation of air transport, taking into account the other approaches developed internationally, where relevant.

Before entering in medias res by analyzing the different features of international air transport liberalization's approaches, it has to distinguish between regionalism and multilateralism concepts.

Professor Wassembergh points out the difference between bilateralism and multilateralism, and he argues that the latter represents "any international cooperation between more than two States."21 Moreover, he makes a distinction between global (or "World-Wide") multilateralism, which encompasses most of the world's States, and regional multilateralism, namely regionalism, which implies cooperation between States of a particular region. ${ }^{22}$ Both these kinds of multilateralism are, in turn, different from plurilateralism, which involves coop-

20 ICAO, Overview, supra note 8, at paragraph 2.7.

$21 \mathrm{H}$. A Wassembergh, The future of multilateral air transport regulation in the regional and global context, 8 Annals of Air and Space Law, 263 (1983). See also B. Stockfish, Opening closed skies: the prospects for further liberalization of trade in international air transport services, 57 Journal of Air Law and Commerce, 639 (1991-1992), who describes multilateralism as "a universal regime encompassing all the nations of the world".

According to ICAO, multilateral regulation "is regulation undertaken jointly by three or more States, within the framework of an international organization and/or a multilateral treaty or agreement, or as a separate specific activity, and may be broadly construed to include relevant regulatory processes and structures, outcomes or output written as treaties or other agreements, resolutions, decisions, directives or regulations, as well as the observations, conclusions, guidance and discussions of multinational bodies, both intergovernmental and non-governmental": ICAO, Manual, supra note 8, at 3.0-1. Moreover, ICAO analyses the arguments favouring and those opposing multilateral international air transport regulation (therein, at 3.3-1, 3.3-2).

22 Wassembergh, supra note 21, at 263. See also Stockfish, supra note 21, at 642-643. On regionalism approach in general see further J. R. Bonin, Regionalism in International Civil Aviation: A Reevaluation of the Economic Regulation of International Air Transport in the Context of Economic Integration, 12 Singapore Year Book Law and Contributors, 113 (2008). 
eration between more than two States regardless of their geographic location and does not include a majority of the world's States. ${ }^{23}$

Some commentators claim that since the aviation industry is currently "overfragmented" regional approaches are necessary to foster and consolidate liberalization initiatives in this sector. ${ }^{24}$ Furthermore, with the creation of regional areas (such as, inter alia, the European Union, ASEAN, APEC, LACAC), the power to negotiate in the field of air transport belongs to groups of States, which act at regional level. ${ }^{25}$

\section{European Union liberalizations in the field of air transport: legal fra- mework, historic development, and current policies.}

\subsection{The Treaty of Rome of 1957 and the progressive shift towards an integrated European market.}

Article 80 of the EEC Treaty of Rome of 1957 lays down that the provisions on common market policy contained in Title IV of the Treaty are applicable to, inter alia, the air transport sector as long as the Council, acting by a qualified majority, decides "whether, to what extent and by what procedure appropriate" to set down provisions. ${ }^{26}$

The Council never enacted these legislative measures, and the European Union liberalizations in the air transport sector were influenced by external factors of the (then) European Economic Community itself. One of these factors was US deregulation, which dates back to October 24, 1978, when Congress passed the Airline Deregulation Act. ${ }^{27}$ Despite this "boost" to EU liberali-

23 Wassembergh, supra note 21, at 263. According to ICAO (ICAO, Manual, supra note 8, at 2.4-1), a plurilateral approach refers to a plurilateral agreement, which could initially be bilateral but be capable of being expanded to involve additional parties, or could, from the start, involve three or more parties, in both cases parties that share similar regulatory objectives which are not so widely held as to make feasible a typical multilateral negotiation. This latter kind of plurilateral agreement is generally open to other States to join (see, for example, the "Kona Agreement").

24 Lelieur, supra note 9, at 117.

25 Lelieur, supra note 9, at 117.

26 J. Balfour, EC external aviation relations: the Community's increasing role, and the new EC/ US agreement, in Common market Law Review, 443 (2008). See also S. Zunarelli and M.M. Comenale Pinto, Manuale di diritto della navigazione e dei trasporti, Padova, 15 (2009).

27 P.S. Dempsey, European Aviation Regulation: Flying Through the Liberalization Labyrinth, 15 Boston College International \& Comparative Law Review, 313 (1992); Balfour, supra note 26, at 443-444; B. Adkins, Air Transport and E.C. Competition Law, London, 21 ff. (1994); B.J.H. Crans, Liberalization of Airports, in Air \& Space Law, 10 (1996), states that US deregulation "boosted the liberalization forces in Europe"; Stockfish, supra note 21, at 613; M. Dupont-Elleray, La politique communautaire de laviation civile, de la liberalization du transport aérien au ciel unique européen, in 224 Revue Française de droit aérien et spatial, 354-355 (2002); Bashor, supra note 6, at 3. 
zations, the path of regulatory reform in these two experiences has not been the same. ${ }^{28}$

The EU air transport liberalization process was gradual, and it implied a progressive shift from a sector controlled tightly by States towards an integrated European market. ${ }^{29}$

In general, regionalism in air transport can only be implemented provided that States are willing to closely coordinate their aviation policies to integrate the interest of their flag carriers into one regional aviation interest. This aim may be reached if States' national air sovereignty merges into one regional air sovereignty, creating a regional air space and a regional flag in the air. ${ }^{30}$ In the EU experience, which remains the most prominent example of regional liberalization in the field of air transport ${ }^{31}$, this close coordination towards regionalism was mostly determined by initiatives taken at the EU level.

Among many regional approaches currently in operation, the EU liberalization process has been the most active. ${ }^{32}$ This trend is continuing, as the EU is currently involved in pursuing liberal agreements with its major partners. ${ }^{33}$

\subsection{The "Nouvelles Frontieres" case and the Single European Act.}

Historically, the EU liberalization process began in 1986, when the EEC's competition law was considered applicable to the air transport sector by the European Court of Justice (hereinafter: ECJ). ${ }^{34}$ This judgment was very important because it enabled the European Commission to intervene in the civil avia-

28 Y-C. Chang and G. Williams, European major airlines' strategic reactions to the Third Package, Transport Policy, 129 (2002); Bashor, supra note 6, at 3.

29 ICAO, A37-WP/5 EC/1, supra note 6, at paragraph 3.4.

30 Wassembergh, supra note 21, at 266. See also B.F. Havel and G.S. Sanchez, Restoring global aviation's "cosmopolitan mentalité", 29 Boston University International Law Journal, 1, at 28-29 (2011), who speak of "interactive" sovereignty as a new meaning of the concept of sovereignty developed above all in the EU, especially after the post-Communist decade since 1989; C.W. Henderson, Understanding International Law, Chichester, 36 (2010), which points out that the EU is the most developed International Government Organization in the world. The Author further notes that the EU is not a "super state", and it «still has a long way to go before it can become the "United States of Europe"», as hypothesized by some European scholars in the past.

31 Stockfish, supra note 21, at 644. See also Havel and Sanchez, supra note 30, at 29; Lelieur, supra note 9 , at 118 .

32 ICAO, Economic Commission, Development and Economic Regulation of International Air Transport, presented by the Council to the ICAO Assembly's 36th Session, A36-WP/16 (June 26, 2007), at paragraph 3.3.

33 ICAO, A37-WP/5 EC/1, supra note 6, at paragraph 3.4.

34 ECJ judgement of April 30, 1986, "Nouvelles Frontieres". It has to be bear in mind that the European legal System sets down a specific regulation in the field of competition law (Articles 101-109 TFUE), which applies to the air transport sector. 
tion policies of individual Member States. ${ }^{35}$ Although this judgment was hailed as a "philosophical victory", it pressured the Council to enact regulations discouraging future litigation. ${ }^{36}$

Another step towards liberalization was the Single European Act, which was passed by the Council in $1986 .{ }^{37}$ Through this Act, the EEC was committed to establishing a European Internal Market by $1992 .{ }^{38}$ This Act was significant because it represented new momentum in European integration so as to complete the internal market. According to Article 8A of the SEA, "internal market shall comprise a market without internal frontiers in which the free movement of goods, persons, services and capital is ensured in accordance with the provisions of this Treaty." Moreover, the SEA replaced the possibility of a single State veto by weighted voting. That way, the possibility to freeze political initiatives due to a one State's opposition was abolished. ${ }^{39}$

35 S.M. Warner, Liberalise Open Skies: Foreign Investments and Cabotage Restrictions keep Noncitizens in second Class, 43 American University LR, 294 (1993); Dempsey, supra note 27, at 338-339; P.S. Dempsey, Aerial Dogfights Over Europe: The Liberalization of EEC Air Transport, 53 Journal of Air Law and Commerce, 655-656 (1987-1988); D. O'Reilly and A. Stone Sweet, The liberalization and reregulation of air transport, 5 Journal of European Public Policy, 454-457 (September 1998); A. Lefebvre D’Ovidio, G. Pescatore, L. Tullio), Manuale di diritto della navigazione, Milano, 49-50 (2008).

36 Dempsey, supra note 27, at 338-339, who notes that the judgment represented a "philosophical victory" for those seeking greater liberalization, and was actually "a practical defeat", since it "created a right without a remedy", at least until either the Council adopted regulations or the Commission issued a reasoned decision.

On this judgment see also Havel, supra note 3, at 402; P.D. Dagtoglou, Air transport and the European Union. Essays and Comments, Athens, 49, 63 ff. (1994); J. Balfour and F.C. Bischoff, European Community Air Law, London, Dublin, Edinburgh, 21 (1995); W.F. Ebke and G.W. Wenglorz, Liberalizing Scheduled Air Transport Within the European Community: From the First Phase to the Second and Beyond, 19 Den. J. Int.l L. \& Pol'y, 494, 507 ff. (1991); A. Loewenstein, European Air Law: Towards a new system of International Air Transport Regulation, Baden-Baden, 56 ff. (1991); M.F. Scharpenseel, Consequences of E.U. Airline Deregulation in the context of the Global Aviation Market, 22 Northwestern Journal of International Law and Business, 102 (2001); O'Reilly and Stone Sweet, supra note 35, at 454 ff.; Dupont-Elleray, supra note 27, at 360.

37 The Single European Act was signed in Luxembourg on February 17, 1986 (OJ L 169 June 29, 1987), by nine Member States, and on February 28, 1986, by Denmark, Italy and Greece. It entered into force on July 1, 1987.

38 Chang and Williams, supra note 28, at 129; J.R. Platt, The Creation of a Community Cabotage Area in the E.U. and its implications for the U.S. Bilateral Aviation System, 17 Air and Space Law, 183 (1992).

39 P.S. Dempsey, European Aviation Law, The Hague, 52-53 (2004); Dempsey, supra note 27, at 354, 358; Dempsey, Aerial Dogfights, supra note 35, at 673; Balfour, supra note 26, at 444; Zunarelli and Comenale Pinto, supra note 26, at 14.

On the SEA see also Ebke and Wenglorz, supra note 36, at 494, 509-510; Scharpenseel, supra note 36, at 95; K. Button and D. Swann, Aviation policy in Europe, in Airline deregulation. International experiences (edited by K. Button), London, 97-98 (1991).

\section{(c) Palacký University Olomouc, Czech Republic, 2011. ISSN 1213-8770 (print), ISSN: 2464-6601 (online).}




\subsection{The three Packages of aviation liberalizations.}

Between 1987 and 1992 the EEC Council enacted the well-known three Packages of aviation liberalization.

The First Package ${ }^{40}$ came into force on January 1, 1988, and its adoption was advocated by the European Commission, which, according to the Nouvelles Frontieres principles set down by the ECJ, was intended to prompt the application of the EEC Treaty competition rules to the air transport sector. ${ }^{41}$

The legislative measures contained in this Package were important inasmuch as some strict rules in Bilateral Air Service Agreements between Member States were superseded by more liberal rules. ${ }^{42}$

In this stage of liberalization, Member States were enabled to designate several of their airlines to operate certain air services, and created new traffic rights. Furthermore, the requirement to share capacity on a 50/50 basis became less strict, and also regulatory supervision on tariffs was reduced. ${ }^{43}$ Finally, block exemptions to competition rules were implemented..$^{44}$

It is clear that EEC institutions were considering this First Package as a transitory passage, in other words, the first step towards the building of a European Internal Market.

The Second Package ${ }^{45}$, which was adopted by the EEC Council in June 1990, basically envisaged a more liberal regime of bilateral agreements, and a greater

40 The First Package includes: Council Regulation 3975/87, 1987, O.J. (L 374) 1, laying down the procedure for the application of the rules on competition to undertakings in the air transport sector; Council Regulation 3976/87, 1987, O.J. (L 374) 10, on the application of Article 85, $\$ 3$, EC Treaty, to certain categories of agreements and concerted practices in the air transport sector; Council Directive 601/87, 1987, O.J. (L 374) 12, on fares for scheduled air services between Member States; Council Decision 602/87, 1987, O.J. (L 374) 19 , on the sharing of the passenger capacity between air carriers on scheduled air services between Member States and on access for air carriers to scheduled air services routes within Member States.

On the First Package of liberalizations see generally Crans, supra note 27, at 10; Dempsey, supra note 35, at 677-682; Balfour and Bischoff, supra note 36, at 15; M. Bartlik, The impact of EU Law on the Regulation of International Air Transportation, Aldershot, 12 (2007); Masutti, supra note 3, at 174-175.

41 Ortiz Blanco and Van Houtte, supra note 3, at 165-166; Dempsey, European, supra note 39, at 55; Dempsey, supra note 27, at 357.

42 Ortiz Blanco and Van Houtte, supra note 3, at 166.

43 Ortiz Blanco and Van Houtte, supra note 3, at 166; Adkins, supra note 27, at 216; D. Gillen, Recent Air Transport Developments in the EU, Presentation to Viessmann Research Centre on Modern Europe, $1^{\text {st }}$ Annual Conference: Developments in Europe, 9, 11 (October 19, 2001); Dempsey, supra note 27, at 359-360; Dempsey, supra note 35, at 677; O’Reilly and Stone Sweet, supra note 35, at 461-462.

44 Dempsey, supra note 27, at 361; Dempsey, supra note 35, at 677. Bashor, supra note 6, at 3; O'Reilly and Stone Sweet, supra note 35, at 454-457.

45 By the Second Package the Council adopted three Regulations: Regulation 2342/90, 1990, 
flexibility on fares and capacity-sharing was reached ${ }^{46}$, without establishing an internal market in the field of air transport. ${ }^{47}$

With the Third Package ${ }^{48}$, which came into force on January 1, 1993, the EEC Council completed the development of a Single European Aviation Market. Based on these legislative measures, if an undertaking satisfies the conditions laid down in those provisions (now contained in Regulation 1008 of 2008), such as professional and technical abilities, financial fitness and an organization such to ensure the safety of operations, that undertaking shall receive an operating license (an authorization) $)^{49}$ granted by a Member State, in order to operate air services within the EU market (in base of freedom of establishing and freedom to provide services), without discrimination on grounds of nationality. The undertaking may also make its own decision regarding fares and capacity. ${ }^{50}$

Therefore, as of 1993, EEC institutions removed capacity restrictions and created traffic rights, these being subject to exceptions for regional services and services operated under a public service obligation regime. ${ }^{51}$ As far as pricing is concerned, Article 22 of Regulation 1008 of 2008 lays down that EU air carriers "shall freely set air fares and air rates for intra-Community services". ${ }^{2}$ Moreover,

O.J. (L 217) 1, on fares for scheduled air services; Regulation 2343/90, 1990, O.J. (L 217)

8 , on access of air carriers and on the sharing of passenger capacity between air carriers; Regulation 2344/90, 1990, O.J. (L 217) 15, which modifies Council Regulation 3976/87.

On the second phase of liberalizations see generally Balfour and Bischoff, supra note 36, at 15; Ebke and Wenglorz, supra note 36, at 493 ff.; Adkins, supra note 27, at 216-219; Bartlik, supra note 40, at 14; Masutti, supra note 3, at 175.

46 Bashor, supra note 6 , at 3 .

47 Ortiz Blanco and Van Houtte, supra note 3, at 166; Dempsey, European, supra note 39, at 55; Adkins, supra note 27, at 217; Gillen, supra note 43, at 11.

48 Council Regulation 2407/92, 1992, O.J (L 240), 1, on the EU licence; Council Regulation $2408 / 92$, 1992, O.J (L 240), 8, on the freedom of access to the EU market; Council Regulation 2409/92, 1992, O.J (L 240), 15, on fares and rates for air services. In addition, are included in this Package: Council Regulation 2410/92, 1992, O.J (L 240), 18; Council Regulation 2411/92, 1992, O.J (L 240), 19. In 2008, the first three Regulations, forming the Third Package, have been replaced by Regulation 1008/2008, 2008, O.J. (L. 293) 3.

On the third phase of liberalizations see generally Havel, supra note 3, at 402; Crans, supra note 27, at 10; Dempsey, European, supra note 39, at 55; Balfour and Bischoff, supra note 36, at 16; Adkins, supra note 27, at 219-235; L. Giani and A. Police, Le funzioni di regolazione del mercato, in Diritto amministrativo (edited by F.G. Scoca), Torino, 525 (2008); Bartlik, supra note 40, at 15-16; Bashor, supra note 6, at 3; Masutti, supra note 3, at 175 ff.; S. Zunarelli, Lezioni di diritto dei trasporti, Bologna, 8-13, (2005).

49 Article 3, Regulation 1008/2008.

50 See Havel, supra note 3, at 407-408. See also Chang and Williams, supra note 28, at 129; Ortiz Blanco and Van Houtte, supra note 3, at 166; Bashor, supra note 6, at 3; Adkins, supra note 27, at 219; Gillen, supra note 43, at 11; Communication from the Commission on the consequences of the Court judgments of 5 November 2002 for European air transport policy, COM (2002), 649 final, at 6 (November 19, 2002).

51 Ortiz Blanco and Van Houtte, supra note 3, at 166; Havel, supra note 3, at 405-406.

52 As it has been pointed out, the 2008 Regulation "abandons the vestigial advance filing 
Article 4 of Regulation 1008/2008 sets down that an undertaking shall be granted the operating license as long as "its principal place of business is located in the licensing Member State" (letter (a)), and that "Member States and/ or nationals of Member States own more than $50 \%$ of the undertaking and effectively control it, whether directly or indirectly through one or more intermediate undertakings, except as provided for in an agreement with a third country to which the Community is a party" (letter (f)). As a consequence, Regulation 1008 "multilateralizes" the Chicago nationality rule. ${ }^{53}$

\subsection{The "EU air carrier" concept. EU ownership and control. Slot allocation. Cabotage.}

The Third Package has introduced the "EU air carrier" concept, which means an air carrier with a valid operating licence granted by a competent licensing authority according to (today) Regulation 1008/2008 (Article 2, No. 11). As a result EU ownership and control has superseded national ownership and control. ${ }^{54}$

After having opened up market access and set airlines free to compete on intra-European Union routes, other two aims had to be reached: full cabotage within the EU market and slot allocation.

Airport slot is a scarce resource; hence, it represents - at least in congested airports - an entry barrier to the air transport common market. As a consequence, despite the adoption of the three Packages, the liberalization process in the field of air transport was not complete yet.

In order to do so, Regulation 95/93 was enacted in $1993^{55}$, which aimed at completing the process at issue. ${ }^{56}$

mechanism for tariffs that had been preserved in the 1992 legislation": Havel, supra note 3, at 403. In the 1992 Regulation, Member States were keeping on controlling tariffs, despite the control was actually an ex-post supervision, limited to ascertain very low or excessive tariffs. See Ortiz Blanco and Van Houtte, supra note 3, at 166; Gillen, supra note 43, at 11.

53 Havel, supra note 3, at 408-409, who observes that the "'control' requirement [...] attempts to deny corporate power to a blocking minority of third-country nationals".

54 ICAO, Liberalizing Air Carrier Ownership and Control, presented by the Secretariat at the Worldwide Air Transport Conference: Challenges and Opportunity of Liberalization, ATConf/5-WP/7, at paragraph 3.2 (October 21, 2002). See also ICAO, Economic Commission, Tourism and air transport liberalization, presented by the World Tourism Organization (UNWTO) to ICAO Assembly's 36th Session, A36-WP/102 EC/12, at paragraph 3.1 (August 24, 2007); IATA, A35-WP/64, supra note 16, at paragraph 3.5; Lelieur, supra note 9, at 119; Havel and Sanchez, supra note 30, at 17.

55 Council Regulation (EEC) No. 95/93 of 18 January 1993, on common rules for the allocation of slots at Community airports O.J. (L 14) 1. The first version of the Regulation 95/93 has been modified by Regulation 793/2004.

56 See the eighth recital of the Preamble to Regulation 95/93. See also Balfour and Bischoff, supra note 36, at 17, 91; K. Bernauw, Airport/Airspace Congestion and Slot Allocation, 28 European transport law, 45 (1993); J. Goh, European Air Transport Law and Competition, 
Airport congestion problems were mostly brought about by liberalizations, after which a "growing imbalance" between the increasing demand of air services and "the availability of adequate airport infrastructure to meet that demand" arose. ${ }^{57}$ Despite Regulation 95/93, the main international airports in the EU are still dominated by the traditional "flag carriers." 58

As far as cabotage is concerned, it is known as a creature of the medieval law of maritime transport ${ }^{59}$, and it prevents foreign air carriers from supplying point-to-point flights within national territory. ${ }^{60}$ Although full cabotage rights to EU air carriers were granted by Regulation 2408/1992, this principle of full freedom of traffic rights was subjected to a compromise, according to which it would not have been applied until April 1, 1997. ${ }^{61}$ As a consequence, from that date onwards all eight freedoms are allowed for EU carriers within the air transport European market. ${ }^{62}$

\subsection{The Open Skies judgments and its aftermath.}

On November 5, 2002, the ECJ pronounced the Open Skies judgments, which represent the starting point of a metamorphosis of international air service agreements. ${ }^{63}$

It is well-known that the cases were brought by the European Commission against eight Member States, which had made open skies bilateral agreements with the US in EU competence areas such as airport slots, air fares and Computer Reservation Systems (CRSs). This way, according to the ECJ, these eight Member States violated not only the external competence of the EU, but also the right of establishment set down in the EC Treaty, since they permitted the US to refuse traffic rights to air carriers designated by a Member State if a substantial part of the ownership and effective control of those carriers was not vested in that Member State. ${ }^{64}$

Chichester, 165 (1997); J.W.F. Sundberg, Airline Deregulation. Legal and administrative Problems, 39 Scandinavian Studies in Law, 448 (2000); Masutti, supra note 3, at $361 \mathrm{ff}$.

57 See the first and the eighth recitals of the Preamble to Regulation 95/93.

58 Button, supra note 1 , at 69 .

59 Havel, supra note 3, at 9.

60 Havel, supra note 3, at 9. "Cabotage" is generally defined as the "carriage of passengers, cargo and mail between two points within the territory of the same nation for compensation or hire": see W.M. Sheenan, Air Cabotage and the Chicago Convention, 63 Harvard Law Review, 1157 (May 1950).

61 Adkins, supra note 27, at 227; Masutti, supra note 3, at 186-187; Gillen, supra note 43, at 11; O'Reilly and Stone Sweet, supra note 35, at 463; R. Abeyratne, US/EU Open Skies Agreement - Some Issues, 72 Journal of Air Law and Commerce, 27 (2007).

62 Chang and Williams, supra note 28, at 129.

63 Bashor, supra note 6, at 2.

64 Bashor, supra note 6, at 4; Dempsey, European, supra note 39, at 88-89; Abeyratne, supra note 61, at 30-31; Bartlik, supra note 40, at 89-93; Masutti, supra note 3, at 151; A.K-J. Tan, Liberalizing Aviation in the Asia-Pacific Region: The Impact of the EU Horizontal Mandate, 
In light of these ECJ judgments, all Member States were required to rectify the bilateral agreements they had made with the US, even though the ECJ did not indicate how this was to be done.

What can be noted is that even in the field of external competence in air transport, EU institutions adopted a progressive approach. ${ }^{65}$

In the aftermath of these judgments, the European Commission issued two Communications. In the first Communication ${ }^{66}$, the European Commission asked to Member States to ensure compliance with the judgments at the earliest possible date, and to refrain from taking international commitments of any kind in the field of aviation before having clarified their compatibility with EU law. As a first step forward in this area, the Commission urged the EU Council to agree a mandate for negotiations to replace the existing bilateral agreements with the US with an agreement at the EU level. ${ }^{67}$ On February 26, 2003, the EU Commission published the second Communication ${ }^{68}$, which concerns relations between the $\mathrm{EU}$ and third countries in the field of air transport. In this Communication, the Commission explained how it intended to proceed with conducting external relations in this field.

On June 5, 2003, the EU Council gave a double mandate to the Commission to open negotiations with the US on an Open Aviation Area, from one side, and to open negotiations with third countries on the replacement of the nationality clauses on the other side.

\subsection{The 2007 EU-US Agreement.}

As far as the first mandate is concerned (also known as the "vertical mandate"), the EC and US delegations were involved in two consecutive sets of negotiations between October 2003 and March 2007. ${ }^{69}$

On April 30, 2007, the US and EU signed an air transport agreement that aimed to supersede the existing bilateral agreements between the $27 \mathrm{EU}$ Member States and the US. ${ }^{70}$ The Agreement entered into provisional application on

31 Air \&Space Law, 443-444 (November 2006); Zunarelli and Comenale Pinto, supra note 26, at 12; Zunarelli, supra note 48, at 13.

65 Communication from the Commission, Developing the agenda for the Community's external aviation policy, March 11,2005, $\operatorname{COM}(2005) 79$, final, at 2.

66 Communication from the Commission, supra note 50.

67 Communication from the Commission, supra note 50, at 63-70.

68 Communication from the Commission on relations between the Community and third countries in the field of air transport, February 26, 2003, COM(2003), 94 final.

69 Havel, supra note 3, at 66; Balfour, supra note 26, at 455; Tan, supra note 64, at 443-447.

70 Havel, supra note 3, at 66; Balfour, supra note 26, at 455; Masutti, supra note 3, at 159; Button, supra note 1, at 64; D.E. Pitfield, The assessment of the EU-US Open Skies Agreement: The counterfactual and other difficulties, 15 Journal of Air Transport Management, 308 (2009). It has been pointed out that since 1995 attempts to get the EU and the US which are the two main aviation regions of the world - together in a so-called Transatlantic 
March 30, 2008. Article 21, paragraph 3 of the Agreement, entitles each party to suspend certain rights if no second stage agreement has been reached by November 30, 2010. In accordance with Article 21, the European Commission began second stage negotiations with the US in May 2008. The Council reviewed the progress made in December 2009 and also in March 2010. After eight rounds of second stage negotiations, an agreement was reached on March 25, 2010, on a draft Protocol to amend the 2007 EU-US Agreement. The aims of the Protocol are: launching a process towards additional foreign investment opportunities in the airline industry, further opening up market access, including further access by EU airlines to US Government financed air transportation, and further strengthening the regulatory cooperation in all fields of aviation policy, particularly on addressing the environmental impact of aviation. ${ }^{71}$ On June 24, 2010, representatives from the US and EU formally signed the "second-stage" Protocol to the 2007 US-EU Air Transport Agreement in Luxembourg. ${ }^{72}$

The Protocol strengthens the cooperation between the two parties, not only through the Joint Committee established under the first Agreement but also by addressing some thorny issues, such as those related to the environment, social protection, competition, and security. Moreover, the Protocol gets rid of the suspension clause set down in Article 21, paragraph 3, of the first Agreement. The parties have, instead, failed to reach an agreement on concessions of investments rights due to the reluctance of the US to modify its current $25 \%$ cap on foreign ownership in US air carriers. A limited compromise was reached, as Article 6, paragraph 2, of the Protocol envisages that the EU "shall allow majority ownership and effective control of their airlines by the United States or its nationals, on the basis of reciprocity, upon confirmation by the Joint Committee that the laws and regulations of the United States permit majority ownership and effective control of its airlines by the Member States or their nationals."

The 2007 EU-US Agreement is an "open sky" agreement, which is different from a "common aviation area" agreement. ${ }^{73}$ Therefore, the 2007 Agreement lays down unlimited third and fourth freedom rights, and fifth freedom rights on beyond routes. As regards pricing, Article 13, paragraph 1, sets down that prices for air transportation services, pursuant to the Agreement, shall be established

Common Aviation Area (TCAA) have been made: see Lelieur, supra note 9, at 122.

71 European Commission, Proposal for a Decision of the Council and the representatives of the Governments of the Member States of the European Union, meeting within the Council on the signature and provisional application of the Protocol to amend the Air Transport Agreement between the European Community and its Member States, of the one part, and the United States of America, of the other part, May 3, 2010, COM(2010) 209 final, Explanatory Memorandum, at 1 .

72 See Press Release, Department of Transportation, U.S. Signs 2nd-Stage U.S.-EU Aviation Agreement, DOT 124-10 (June 24, 2010), available at http://www.dot.gov/affairs/2010/ dot12410.html.

73 Balfour, supra note 26, at 455. 
freely and shall not be subject to approval nor be required to be filed, except as provided for in paragraph 2 of the same Article. Seventh freedom rights are more restricted. $^{74}$

The most important provision in the 2007 EU-US Agreement allows any EU airline to operate between any point in the US and any point in the EU..$^{75}$ Cabotage, however, is not covered by the Agreement. ${ }^{76}$

\subsection{The "horizontal mandate" and Regulation 847/2004.}

With regard to the second mandate (also known as the "horizontal mandate") $)^{77}$, the EU Council authorized the Commission to carry out simultaneous bilateral treaty revisions with non Member States (apart from the US) to bring the air services agreements concluded between these States and the EU Member States into compliance. ${ }^{78}$ As a result, in 2004 the European Parliament and the Council adopted Regulation $847^{79}$, which represents the new legal framework of EU air services negotiations as it allows the EU Member States to exercise the "horizontal mandate." ${ }^{80}$ In other words, Regulation 847/2004 allows Member States to enter into negotiations with third countries to stipulate new air service agreements, or to modify the existent air service agreements, their

74 See Balfour, supra note 26, at 455-456; Masutti, supra note 3, at 161.

75 Balfour, supra note 26, at 456; Pitfield, supra note 70, at 308.

76 WTO, Report of the Second Session of the Review Mandated under Paragraph 5 of the Annex on Air Transport Services held on 2 October 2007, S/C/M/89, at 35 (November 19, 2007).

77 Generally, horizontal agreements can correct existing air service agreements through two different methods. Firstly, bilateral negotiations between each Member State concerned and its partners can operate. In this option, each bilateral air service agreement has to be amended separately. Secondly, it is possible to negotiate single horizontal agreements, through which the Commission acts on a mandate of the EU Member States. This method has the advantages of simplicity, costs, and speed. Indeed, according to this latter approach, between June 2003 and December 2008 it has led to changes with 37 partner States and one regional organization with 8 Member States representing 651 bilateral agreements. With the former method, 132 bilateral agreements with 60 third countries have been amended: see http://ec.europa.eu/transport/air/international_aviation/external_aviation_policy/ horizontal_agreements_en.htm.

Currently, there are 46 such horizontal aviation agreements between the EU and partner countries worldwide. To date, more than 900 bilateral Air Service Agreements have been modified: see EU, Press Releases, EU and Indonesia sign deal that will boost air transport (June 30, 2011).

78 Havel, supra note 3, at 66; P. Van Fenema, EU Horizontal Agreements: Community Designation and "free rider" clause, 31 Air \& Space Law, 172 (2006); Balfour, supra note 26, at 448-449; Tan, supra note 64, at 447.

79 Regulation 847/2004 of the European Parliament and of the Council of 29 April 2004, on the negotiation and implementation of air service agreements between Member States and third countries, in OJEU L 157 of 30 April 2004.

80 See Abeyratne, supra note 61, at 31. See also Masutti, supra note 3, at 162-164.

\section{(c) Palacký University Olomouc, Czech Republic, 2011. ISSN 1213-8770 (print), ISSN: 2464-6601 (online).}


annexes, or any other related bilateral or multilateral arrangement that falls partly within the competence of the EU. ${ }^{81}$

Since 2004, the European Union has proposed to launch targeted negotiations to achieve comprehensive air transport agreements with selected partners all over the world, with the aim of strengthening and promoting the European industry and ensure fair competition on one side, and to seek to reform of international civil aviation on the other side. ${ }^{82}$ In light of this, the EU has modified existent agreements and concluded new agreements.

2.8 Some recent air transport agreements between the European Union and third parties.

\subsubsection{The EU and Canada Agreement.}

Recently, a new agreement on air transport has been concluded between the EU and Canada. The Agreement was signed on November 30, 2008, in London, and was politically endorsed by the EU-Canada summit on May 6, 2009. The Agreement allows airlines to operate direct flights to Canada from anywhere in Europe, and it removes all restrictions on routes, prices, or the number of weekly flights between the two countries involved. Other traffic rights will be liberalized gradually. Moreover, the EU and Canada will cooperate closely in the fields of security and the environment. ${ }^{83}$

\subsubsection{The EU and Brazil negotiations on several agreements.}

A strong cooperation between the EU and Brazil in the field of civil aviation has developed since 2007. An agreement on certain aspects of air services ("Horizontal Agreement") between the EU and Brazil was negotiated in early 2009. ${ }^{84}$ In December 2009, negotiations of a bilateral agreement on civil aviation safety between the EU and Brazil began. An EU-Latin America civil aviation summit was organized jointly between the EU and Brazil in Rio de Janeiro on May 24-26, 2010. ${ }^{85}$ Many important issues were addressed during the summit, such as the abolition of barriers to air transport in the EU and Latin America. ${ }^{86}$

81 Article 1.

82 See Communication from the Commission, Developing an EU civil aviation policy towards Brazil, $\operatorname{COM}(2010)$ 210, final, at 1.1 (May 5, 2010).

83 EU Press release, EU and Canada sign Air Transport Agreement, IP/09/1963 (December 17, 2009). See also Havel and Sanchez, supra note 30, at $22 \mathrm{ff}$.

84 European Commission, Proposal for a Council Decision on the signature of the Agreement on certain aspects for air services between the European Community and the Federative Republic of Brazil, August 3, 2009, $\operatorname{COM(2009)} 411$ final. On October 9, 2009, the Council authorised the signature of the agreement.

85 Communication from the Commission, supra note 82, at 1.2.

86 EU Press release, Vice-President Kallas leads high-level delegation to the EU-Latin America civil aviation summit, IP/10/591 (May 21, 2010).

\section{(c) Palacký University Olomouc, Czech Republic, 2011. ISSN 1213-8770 (print), ISSN: 2464-6601 (online).}


At the summit, European Commission Vice-President Siim Kallas together with Brazil's Minister of Defence Mr Nelson Jobim, and Mr José Blanco, Transport Minister of Spain, announced that the negotiations on two important agreements between Brazil and the EU had been finalized. In particular, negotiations focused on an agreement on certain aspects of air services (the above mentioned "Horizontal Agreement") and an agreement on aviation safety. ${ }^{87}$

Moreover, as for air safety, on May 21, 2010, the European Commission put forward a proposal for a Council Decision on the signature of an agreement between the EU and Brazil. ${ }^{88}$ The EU and Brazil will cooperate also in the specific field of the environment to mitigate the climate change impact of aviation. ${ }^{89}$

In general, at the same summit, two "joint declarations" between the EU and Latin America aviation leaders were signed. These commitments will lay the foundation for closer cooperation in the field of civil aviation between the EU and Latin America. ${ }^{90}$

On March 18, 2011, the European Commission vice-President Siim Kallas, responsible for transport, announced that negotiators from the EU and Brazil have initialed a comprehensive agreement on air transport services. ${ }^{11}$ This breakthrough in EU-Brazil negotiations is significant for the further development of the strategic partnership between the countries involved. According to the Agreement, all EU airlines will have the ability to operate direct flights to anywhere in Brazil from anywhere in Europe. The Agreement will remove all restrictions on routes, prices, and the number of weekly flights between the countries involved. Another key point of the agreement lies in the close cooperation between the EU and Brazil on a number of areas, including competition law, safety, security, environment, air traffic management, consumer protection, and social and labour issues. ${ }^{92}$

87 The horizontal agreement modernizes the existing legal framework and establishes full legal certainty for all air carriers operating flights between the two markets (the EU and Brazil) involved. The aviation safety agreement will expand the cooperation between the EU and Brazil in all areas of safety facilitating trade in aeronautical products and services. The two agreements were expected to be signed at the EU-Brazil Summit in Brasilia on July 14, 2010 (see EU Press release, EU and Latin America agree to Strengthen cooperation in civil aviation, IP/10/608 (May 25, 2010)), but they were not. However, at the summit two joint declarations between the EU and Latin America aviation leaders were signed: see infra.

88 European Commission, Proposal for a Council Decision on the signature of an agreement between the European Union and the Government of the Federative Republic of Brazil on civil aviation safety, May 21, 2010, $\operatorname{COM(2010)~} 268$ final.

89 Communication from the Commission, supra note 82, at 3.3.

90 EU Press release, IP/10/608, supra note 87.

91 EU Press release, Breakthrough in EU-Brazil negotiations on far-reaching aviation agreement, IP/11/327 (March 18, 2011).

92 EU Press release, IP/11/327, supra note 91. 


\subsubsection{The EU and Turkey negotiations.}

Among the most recent initiatives between the EU and third countries, it is important to note that on March 25, 2010, the European Union and Turkish authorities initiated an aviation agreement with the aim to remove nationality restrictions in the bilateral air service agreements between EU Member States and Turkey. The Agreement allows any EU airline to operate flights between any EU Member State and Turkey, providing a bilateral agreement with Turkey exists and traffic rights are available. The Agreement opens the way for further cooperation between the EU and Turkey in the field of civil aviation, including in the areas of aviation safety, security, air traffic management, technology, research and industrial cooperation, consumer and environment protection, and competition. ${ }^{93}$

\subsubsection{The EU and Mexico Agreement.}

Another very recent aviation agreement was signed on December 15, 2010, between the EU and Mexico. The Agreement aims at removing nationality restrictions in the bilateral air services agreements between the countries involved.

Like others, this horizontal Agreement allows any EU airline to operate flights between any EU Member State and the third country, in this case Mexico, where a bilateral agreement with that country exists and traffic rights are available. ${ }^{94}$

\subsubsection{The EU and Russian negotiations. The Siberian overflight charges issue.}

Currently a very small number of third countries, among which Russia, still do not accept the new European Union legal framework ${ }^{95}$, according to which, inter alia, bilateral air service agreements between an individual Member State and a non-EU country have to include an "EU designation clause" recognizing that the terms apply equally to all EU airlines, and not just the airlines of that Member State. ${ }^{96}$ Most agreements with non-EU countries have complied with this legal framework, but Russia fails to recognize that all EU carriers must be treated equally, and that the terms of any bilateral agreement must include an "EU designation clause" and apply to all.

93 EU, Press Releases, EU and Turkey initial civil aviation agreement, IP/10/369 (March 25, 2010).

94 EU, Press Releases, EU and Mexico sign civil aviation agreement (January 5, 2011).

95 We obviously refer to the current European Union legal framework, derived from the liberalization process which started in the EEC in the early 1990s, when a single European aviation market was created and when the Open Skies rulings of 2002 were pronounced by the ECJ (as we have already seen above in this paragraph 2).

96 EU, Press Releases, Air transport: Commission launches infringement procedures against France, Germany, Austria and Finland over agreements with Russia on Siberian overflights, IP/10/1425 (October 28, 2010). 
Moreover, EU airlines are obliged to pay Siberian overflight charges for routes to many Asian destinations. These charges, imposed by Russia in the bilateral agreements with Member States through mandatory commercial agreements between EU airlines and Aeroflot, are not related to normal payments for Air Traffic Control services ${ }^{97}$ and are clearly in breach of Article 15 of the Chicago Convention, according to which "no charge shall be imposed by any Contracting State solely for the right of transit over or entry into or exit from its territory of any aircraft of a Contracting State or persons or property thereon." ${ }^{\text {"98 }}$ Furthermore, the charges seem to be incompatible with EU competition laws, as airlines are forced into concluding a commercial agreement with a direct competitor.

In short, the bilateral aviation agreements between Russia and Member States hinder competition, breach EU rules on freedom of establishment ${ }^{99}$, and provide a basis for Siberian overflight charges, which are illegal.

This is why the European Commission has launched infringement procedures against the Member States involved. ${ }^{100}$ Essentially, the Commission has not activated Article 15 of the Chicago Convention, as the EU is only an "observer" and not a Party to the ICAO. ${ }^{101}$

97 Communication from the Commission to the European Parliament and the Council, $A$ Framework for Developing Relations with the Russian Federation in the Field of Air Transport, $\operatorname{COM}(2005)$ 77, final, at 3.2.2.1 (March 14, 2005).

98 In 2004, Russian government submitted a commitment to the European Commission, according to which the system of overflight payments would be abolished by 2013. An agreement ("Agreed Principles") between the European Commission and the Russian Federation on the abolishment of overflight payments by 2013 was initialled in 2006 at the EU-Russia summit held in Helsinki, but to date the agreement was adopted only by the EU Council in 2007. In 2005, the Commission proposed a framework to enhance cooperation with the Russian Federation in the field of aviation (Communication from the Commission, supra note 97), but it could start after the implementation of the "Agreed Principles": see http://ec.europa.eu/transport/air/international_aviation/country_index/ russia_en.htm.

99 These illegalities need to be addressed in the context of a future EU-Russia air transport agreement: see Communication from the Commission, supra note 97, at 3.2.1.

100 From October 28, 2010, to May 19, 2011, the European Commission launched infringement procedures against $26 \mathrm{Member}$ States. The last infringement procedure was launched against Romania, and the Commission is now assessing the compliance with EU law of the remaining Member State's bilateral aviation agreement with Russia: see EU, Press Releases, Air transport: Commission launches infringement procedures against Romania over agreements with Russia on equal treatment of EU airlines, IP/11/586 (May 19, 2011).

$101 \mathrm{EU}$, Press Releases, Air transport: Infringements concerning bilateral aviation agreements with Russia, MEMO/11/167 (March 14, 2011). On this point, more in general, see European Commission, The European Community at ICAO, available online at http:// ec.europa.eu/transport/air/international_aviation/european_community_icao/european_ community_icao_en.htm. Notwithstanding, in 1997 the Council welcomed the initiative of the Commission to start direct consultations with the Russian Federation on this issue: see Communication from the Commission, supra note 97, at 4.4.

As concerns the most recent developments on the relationship between the EU and ICAO, 


\section{Effects of European Union liberalizations.}

\subsection{Benefits: a) on intra-EU market.}

It has been argued that the effects of EU liberalizations were less significant than in the US, because in the former there has been no dramatic decline in fares, no spectacular disappearances of major carriers, and no substantial penetration of traditional domestic markets by foreign competitors. ${ }^{102}$ As a matter of fact, recent statistics and data show that European liberalizations have shifted European Union air transportation.

According to IATA, only $17 \%$ of international air traffic is operated in a deregulated environment, and full liberalization to the eighth freedom was achieved only within the EU. ${ }^{103}$

The opening up of the market in the field of air transport has led to more efficiency and lower costs. Indeed, the number of cross-border intra-EU routes increased by $220 \%$ between 1992 and 2009, and intra-EU routes with more than two competitors increased by $415 \%$ (from 93 to 479 ) during the same period. ${ }^{104}$ Today low-cost carriers represent over a third of total intra-EU scheduled capacity. ${ }^{105}$ As Vice-President of the European Commission has recently noted, the EU air transport liberalization has led to concrete benefits for businesses and consumers, since the frequency of flights has increased by $78 \%$, while the standard cost of flights has decreased by $66 \%$. At the same time, connections to islands or remote territories are ensured through public service obligations. ${ }^{106}$

Air traffic in Europe has tripled between 1980 and 2000, and if demand for air traffic continues in line with current trends, this will double again in 20 years. ${ }^{107}$

an important Memorandum of Cooperation was signed by the European Commission and ICAO on May 4, 2011: see EU, Press Releases, Commission signs Memorandum of Cooperation with the International Civil Aviation Organization, IP/11/540 (May 4, 2011).

102 See Gillen, supra note 43, at 11.

103 IATA, Airline Liberalization, Geneva, at 16 (2007).

104 D. Calleja, Aviation in the European Union - An overview, Speech given at the EU-Latin America Civil Aviation Summit, held in Rio de Janeiro on May 24-26, 2010. The data confirms those contained in the Communication from the Commission, A sustainable future for transport: Towards an integrated, technology-led and user friendly system, $\operatorname{COM(2009)~}$ 279 final, at 3, No. 8 (June 17, 2009). More recently, see EU, Money where it matters - how the EU budget delivers value to you, MEMO/11/469, at 4 (June 29, 2011).

105 Communication from the Commission, $\operatorname{COM}(2009) 279$ final, supra note 104, at 3, No. 8. $106 \mathrm{~J}$. Almunia, The role of public services in "Europe 2020", Speech given at CEEP Congress held in Madrid on May 31, 2010 (Speech/10/276), available at http://europa.eu/rapid/ pressReleasesAction.do? reference $=\mathrm{SPEECH} / 10 / 276 \&$ format $=$ HTML\&aged $=0$ \&language $=$ EN\&guiLanguage $=$ en.

107 See Communication from the Commission to the Council, the European Parliament, the European Economic and Social Committee and the Committee of the Regions, An action plan for airport capacity, efficiency and safety in Europe, $\operatorname{COM(2006)~} 819$ final (January 24, 2007), where it is pointed out that the liberalization of the European air transport sector is a 
Of all the different modes of transport, air transport has shown the largest increase over the last twenty years by far. Expressed in passenger/kilometres, air traffic has increased by $7,4 \%$ a year on average since 1980 , while the traffic handled by the airports of the Fifteen has shown a five-fold increase since $1970 .^{108}$

In 2005, the total number of passengers transported by air in the EU25 rose to more than 700 million, or $8,5 \%$ when compared with 2004 . Passenger numbers rose by $8,8 \%$ in 2004 and by $4,9 \%$ in $2003 .{ }^{109}$

The total number of passengers transported by air in the EU27 rose to 793 million in 2007 , or $7,3 \%$ when compared with 2006 . In 2006 , passenger numbers in the EU27 rose by $4,7 \% .^{110}$

Due to the economic crisis, the total number of passengers transported by air in the EU27 rose to 798 million in 2008 , or by just $0,6 \%$ when compared with 2007. This was the lowest annual growth rate in the EU since 2002.111

From the first part of 2009, monthly data shows that the total number of passengers in the EU27 who were transported by air came to 343 million. In the first quarter of 2008-2009, there was a decrease by $13,79 \%$, while the number of passengers fell by $7,4 \%$ in the second quarter of the same period. ${ }^{112}$ In the last

major success: air traffic in Europe tripled between 1980 and 2000. Between 1992 and 2005 the number of intra-EU routes increased by $150 \%$. European citizens can now enjoy a diversified range of air services at an affordable price (therein, at 2, No. 1). If demand for air traffic continues in line with current trends, it will double in 20 years (therein, at 2, No. 2).

108 European Commission, White Paper, European Transport Policy for 2010: time to decide, $\operatorname{COM}(2001) 370$ final, at 35 .

109 Eurostat, Air Transport in the EU 25, Air passenger transport up by $8,5 \%$ in 2005, News release, 11/2007 (January 19, 2007).

110 Eurostat, Air transport in the EU27, Air passenger transport up by 7\% in 2007, News release, 6/2009 (January 13, 2009).

In 2007, the highest numbers of passengers were registered in the United Kingdom (217 $\mathrm{mn},+3 \%)$, Germany $(164 \mathrm{mn},+6 \%)$, Spain $(164 \mathrm{mn},+9 \%)$, France $(120 \mathrm{mn},+6 \%)$ and Italy $(106 \mathrm{mn},+11 \%)$. Detailed figures of the year 2007 have been published in a report by Eurostat, the Statistical Office of the European Communities, on air transport in the EU27 in 2007 (Eurostat, Statistics in Focus 1/2009, Air passenger transport in Europe in 2007).

111 Eurostat, Air transport in the EU27, Air passenger transport up by 0.6\% in 2008. Declining trend through the year, News release, 174/2009 (December 4, 2009).

Quarterly data for 2008 helps to evaluate the impact of the economic crisis on air transport, and shows a declining trend through the year. Passenger numbers rose by $6,1 \%$ in the first quarter of 2008, compared with the same quarter of 2007 , and by $3,0 \%$ in the second quarter, then they fell by $0,4 \%$ in the third quarter and by $5,6 \%$ in the fourth quarter.

In the EU27, the number of passengers on extra-EU flights rose by $4,2 \%$ in 2008 , compared with 2007 , to 282 million. The number of passengers decreased by $0,5 \%$ to 345 million on intra-EU flights, and by $2,9 \%$ to 171 million on national flights.

These figures are published in a report by Eurostat, the Statistical Office of the European Communities, on air transport in the EU27 in 2008 (Eurostat, Statistics in Focus 91/2009, "Air passenger transport in Europe in 2008").

112 Eurostat, Passenger air transport - monthly data for the first half of 2009, April 15, 2010. 
quarter of 2009, the situation did not change. However, in the second half of the year, there were signs of recovery. Recent data indicates that compared to 2008, 2009 witnessed a decrease of $6 \%$ in the total number of air passengers transported by air in the EU27.

In 2009, in terms of on intra-EU flights, the number of passengers decreased by $8 \%$ to a total of 318 million. On extra-EU flights there was a $4 \%$ decrease to a total of 271 million. Finally, on national flights there was a $5 \%$ decrease to a total of 162 million. ${ }^{113}$

As far as airports are concerned, European airports directly employ 156.000 staff, and airport sites play host to a total of 1.200 .000 employees. Airport-related jobs in Europe amount to $€ 59$ billion in annual contribution to GDP. ${ }^{114}$

Moreover, the demand for new airplanes in Europe is expected to go up to 7190 between 2010 and 2029. In the same period, there will be a higher demand for new airplanes in the Asia Pacific Region and in North America, which will grow to 10320 and 7200 respectively. ${ }^{115}$

The growth of the European air transport since 1995 has boosted the European Union GDP by $4 \%$.

The expected growth on the GDP of the 27 European countries by 2025 is $1,8 \% .{ }^{116}$ In terms of GDP, the European economy is expected to increase by $1,9 \%$ between 2010 and 2029, while air traffic (RPK) is expected to increase by $4,4 \%{ }^{117}$

In terms of Revenue Passenger Kilometres (RPKs), the Airline Passenger Traffic within Europe experienced a steady growth between 2001 (449,3 billion) and 2008 (660,5 billion), while, in 2009 the traffic decreased slightly by 35 billion compared to that in 2008 , and reached 624,9 billion. It is expected to increase by about $4,1 \%$ between 2010 and 2029, reaching $1.409,1$ billion in 2029. ${ }^{118}$

Overall, it can be argued that the internal air transport market has become an industrial reality and is an engine for growth. Restructuring and integration are well advanced, and the market has been broadened with the multiplication of routes served in Europe, the entry of low-cost carriers, and the development

113 Eurostat, Air passenger transport down by $6 \%$ in 2009. Signs of recovery in second half of 2009, News release 17/2011, January 31, 2011.

114 O. Jankovec, Removing barriers for air transport \& unleashing the power of airports, Speech gave at the EU-Latin America Civil Aviation Summit, held in Rio de Janeiro on May 24-26, 2010.

115 See Boeing, Current market outlook 2010-2029, at 9.

116 The Economic Catalytic Effects of Air Transport in Europe, Eurocontrol Experimental Centre Bretigny Sur Orge Cedex (2005). Internationally, IHS/Global Insight forecasts an average $3,5 \%$ growth in the world GDP for the next three years: ICAO News Release, ICAO medium-term forecast points to continued industry growth through 2013, PIO 15/11 (July 19, 2011).

117 Boeing, supra note 115, at 14 .

118 Boeing, supra note 115, at 19. 
of regional airports. The internal market has brought considerable benefits to customers $^{119}$. The EU is a major world player both in air transport equipment and aviation services. ${ }^{120}$

\section{b) on air cargo.}

European Union liberalizations had a significant impact in the air cargo industry too. In the EU, although the direct effects of liberalization were considerably less when compared to the US cargo deregulation of 1977, due to the fact that air cargo in the internal market plays a limited role compared to other transport modes, such as rail and road, the EU reforms represented an important point for set wider air transport liberalizations. Open skies agreements fostered air cargo services in bilateral routes and facilitated hub-and-spoke operations. ${ }^{\mathbf{1 2 1}}$ Intra-Europe air cargo grew by 3,7 \% in 2007. ${ }^{122}$ Air cargo (RTK) will increase by $5 \%$ between 2010 and 2029. ${ }^{123}$

\section{c) on EU-third countries markets.}

With regard to the 2009 EU-Canada Agreement, 2008 data shows that more than 9 million people travelled between the two countries. When the Agreement was signed, eight EU Member States did not have yet an agreement with Canada, and even the Member States already had one, it was not as liberal as the 2009 Agreement as it did not offer full access to the respective markets. The Agreement is expected to bring economic benefits of at least $€ 72$ million and create more than 1000 direct jobs in the first period. The number of passengers in the open aviation area between the EU and Canada is expected to increase by 3,5 million in the first few years. ${ }^{124}$

As far as the EU and Brazil negotiations are concerned, recent data indicates that 4,4 million passengers travel each year between the EU and Brazil, and there are high growth rates of air traffic between the EU and South America. ${ }^{125}$

119 See Communication from the Commission to the Council and to the European Parliament, The EU and the neighbouring regions: A renewed approach to transport cooperation, $\operatorname{COM}(2011) 415$ final, at 1 (July 7, 2011).

120 Communication from the Commission to the Council and the European Parliament, Keep Europe moving - sustainable mobility for our continent. Mid-term review of the European Commission's 2001 Transport White Paper, $\operatorname{COM}(2006) 314$ final, at 3.2 (June 22, 2006). See also K. Button, Deregulation and Liberalization of European Air Transport Markets, 14 Innovation, 261-265 (2001); Button, supra note 1, at 64 .

121 OECD, Liberalization of Air Cargo Transport, document DSTI/DOT(2002)1/REV1, Paris (2002).

122 Boeing, World Air Cargo Forecast 2008-2009.

123 Boeing, supra note 115, at 14.

124 EU Press release, IP/09/1963, supra note 83.

125 Communication from the Commission, supra note 82, at 1.2. See also EU Press release, EU to negotiate an ambitious air transport agreement with Brazil, IP/10/1342 (October 17, 2010); EU Press release, IP/11/327, supra note 91. 
Data published by the Brazilian Civil Aviation Authority (ANAC) confirm that the air transport market is growing to and from Brazil. Over the last five years there was an increase in the number of passengers carried, number of the served cities, and rate of frequencies per city (638 in 2005 to 771 in 2008). Moreover, new routes have been established in 2008-2009. ${ }^{126}$

According to the European Commission, an agreement between the EU and Brazil concerning the gradual opening of market access would bring economic benefits to air carriers, airports, passengers, shippers, tourism, and the economies of the countries involved. ${ }^{127}$

A recent study, undertaken on behalf of the European Commission, shows that opening aviation markets between the EU and Brazil could generate up to $€ 460$ million consumer benefits per year. ${ }^{128}$ The Study indicates other economic benefits of an agreement between the EU and Brazil. Firstly, airlines would be able to expand their services due to the removal of bilateral capacity and frequency restrictions. Secondly, competition would be fostered because of the removal of price controls. Thirdly, airlines will be able to offer wider network connectivity to their passengers due to the removal of code share restrictions. Fourthly, new entrants would be enabled to introduce new services in the relevant market thanks to the removal of the limitation on the number of designated airlines. Finally, air cargo in the two markets would benefit from an agreement. ${ }^{129}$ Another important consequence of such an agreement would be the reform of the regulatory framework governing air services between the EU and Brazil. ${ }^{130}$

Notwithstanding, it will be safeguarded by the principle of reciprocity, which is a cornerstone in the Brazilian Aeronautical Code and special aviation laws and regulations.

Thanks to this legal framework, it is likely that reciprocal benefits will be achieved, at a bilateral level, in a modernized regulatory framework between the EU and Brazil. ${ }^{131}$ This will make it possible to reach a "normalization" of the international aviation industry, because the agreement between them will gradually

126 S.P. Vieira, Removing Barriers for Air Transport, Speech gave at the EU-Latin America Civil Aviation Summit, held in Rio de Janeiro on May 24-26, 2010.

127 Communication from the Commission, supra note 82, at 1.4. See also EU Press release, European Commission proposes to open the aviation market with Brazil, IP/10/546 (May 6, 2010); EU Press release, IP/10/1342, supra note 125.

$128 \mathrm{Booz} \& \mathrm{Co}$, The Economic Impacts of Opening Aviation Markets between the EU and Brazil (June 2009), online at http://ec.europa.eu/transport/air/international_aviation/country_ index/study_brazil_EN.

129 Booz \& Co, supra note 128 . The economic benefits as indicated above are summarized in the Communication of the Commission cited supra note 82, at 3.2.

130 Communication from the Commission, supra note 82 , at 1.4.

131 Communication from the Commission, supra note 82 , at 3.3. 
remove outdated restrictions on prices and traffic rights and will facilitate cooperation between the authorities, even for international matters. ${ }^{132}$

More generally, the number of passengers within the Latin America air transport area doubled between 1997 and 2008. This market is forecast to be among the fastest growing in the world over the next 20 years. According to the European Commission, the number of passengers travelling between these two markets will exceed 20 million each year. ${ }^{133}$

With regard to the EU-Turkish civil aviation cooperation, recent data indicates that passenger traffic between the EU and Turkey exceeded 25 million people in 2008, making Turkey the third largest external aviation market for the EU in number of passengers, after the United States and Switzerland. ${ }^{134}$

The recent EU-Mexico civil aviation agreement, signed in December 2010, also aims to strengthen relations and encourage traffic between the countries involved. ${ }^{135}$

As concerns the EU-Russian aviation market, it has been pointed out that Russian international passenger traffic is largely concentrated on European destinations, and further growth is forecast. Currently, about $75 \%$ of all Russian passenger traffic is directed toward European destinations. ${ }^{136}$

Recent data indicates that air traffic has risen significantly in Russia. According to the Russian Federal Aviation Agency, the first quarter of 2010 showed a $33,5 \%$ increase following a 9,4 \% drop in Russian domestic air traffic during $2009 . .^{137}$

The growth potential of the Russian market is widely recognized. Along with China, Russia is one of the largest "high potential" tourist markets in the world. ${ }^{138}$

According to a study carried out on behalf of the Commission, a fully open market between the EU and Russia could create benefits of up to $€ 680$ million per annum for both sides, by virtue of job creation in the aviation industry, expenditure by tourists and travelers, and support services to the wider aviation industry. ${ }^{139}$

Another significant economic benefit would derive from the phasing-out of Siberian overflight payments. As a consequence, substantial savings would be

132 EU Press release, IP/11/327, supra note 91.

133 EU Press release, IP/10/591, supra note 86.

134 EU, Press Releases, IP/10/369, supra note 93.

135 EU, Press Releases, EU and Mexico, supra note 94.

136 Communication from the Commission, supra note 97, at 1 and 3.

137 Boeing, supra note 115, at 17.

138 Communication from the Commission, supra note 97, at 3.1.

139 Communication from the Commission, supra note 97, at 4.1. 
made by EU airlines and it would create a more liberal environment for expanding services to the Far East over Russia would be created. ${ }^{140}$

\section{d) on the 2007 Open Aviation Area between the US and the EU.}

As regards the Open Aviation Area between the US and the EU, the 2007 EUUS Air Transport Agreement represented a significant change in transatlantic aviation relations, providing broad new commercial freedoms for airlines and a comprehensive framework for regulatory cooperation with the United States on a wide range of issues. The Agreement created substantial benefits for airlines, airports, and air transport users in Europe. ${ }^{141}$

A 2007 report analysed the potential economic benefits from establishing the agreement. ${ }^{142}$ According to the Report, the removal of restrictions imposed by the bilateral agreement system should result in new routes and market entrants, generating 26 million additional passengers over five years, and this represents an estimated increase in growth of $6,4 \%$. The removal of output constraints will be worth - in terms of consumer surplus - between $€ 6,4$ and $€ 12$ billion over the five year period. Moreover, it will be created 72.000 jobs because additional demand requires additional resources. Economic benefits will also concern the cargo market, which should increase between 100.000 and 170.000 tonnes of freight. As a consequence, between five and nine-thousand new jobs will be generated.

The Open Aviation Area aims at extending full freedoms of the air to both parties, removing restrictions on investment by foreign entities and permitting wet leasing of aircraft under non discriminatory and transparent conditions. ${ }^{143}$ Likewise, cabotage and investment rights should be extended within EU and US carriers and within the EU Member States to US carriers. ${ }^{\mathbf{1 4 4}}$

140 Communication from the Commission, supra note 97, at 4.1.

141 European Commission, Explanatory Memorandum, supra note 71, at 1.

142 Booz, Allen, Hamilton, The economic impacts of an open aviation area between the EU and the US, Executive Summary, prepared for Directorate General Energy and Transport European Commission (January 2007). This Report is an updating of the previous one commissioned to the Brattle Group by the European Commission in 2002, concerning The Economic Impact of an EU-US Open Aviation Area, Washington D.C. These and other Reports (carried out previously) are summarized in Button, supra note 1, at 67-69. See also B. Humphreys and P. Morrell, The potential impacts of the EU/US Open Sky Agreement: What will happen at Heathrow after spring 2008, 15 Journal of Air Transport Management, 73 (2009); Pitfield, supra note 70, at 309-310.

$143 \mathrm{Booz}$, Allen, Hamilton, supra note 142, at iii.

144 Booz, Allen, Hamilton, supra note 142, at xii. 
e) on the implementation of the freedom of movement of EU citizens within the European Union.

It is already well-known ever since the adoption of the Maastricht Treaty that the European Union has superseded the European Economic Community ${ }^{145}$, with the consequence that the Community system has become more political than it previously was. ${ }^{146}$

In this respect, the European Commission significantly points out that " $[\mathrm{i}] \mathrm{n}$ a modern society connectivity is the basis for economic competitiveness, social and regional cohesion and cultural development", with the consequence that "not only do the economic and commercial needs of globalization drive the growing demand for air transport," but such demand is also "boosted by evolving societal and cultural needs." ${ }^{47}$

In this new political scenario, thanks to some factors - the broadening of the European Union's membership, the establishing of EU citizenship, which has allowed every person holding the nationality of a Member State, without replacing national citizenship (Article 20, TFEU) ${ }^{\mathbf{1 4 8}}$, the freedom of establishment (Articles $49 \mathrm{ff}, \mathrm{TFEU}$ ) and the freedom of movement of persons, goods, services, and capital (ex Article 26, $\$ 2$, and Articles $45 \mathrm{ff}$, TFEU) within the Union - air transport became the most important method to make effective the exercise of these freedoms and rights. ${ }^{149}$ Moreover, we can say that nowadays air transport is decreasingly reserved to upper-class people (just like it was until the liberalization Era), but it is more open to everyone (thanks to low cost flights) ${ }^{150}$.

145 See G. Tesauro, Diritto comunitario, Padova, at 9 (2008); G. Strozzi, s.v. Istituzioni comunitarie, in Dig. disc. pubbl., Torino, 384, at 384 (2000). See also Scharpenseel, supra note 36, at 101; Giani and Police, supra note 48, at 505-506; Abeyratne, supra note 61, at 27-28.

146 European Commission, EU citizenship report 2010, Dismantling the obstacles to EU citizens's rights, $\operatorname{COM}(2010) 603$ final, at 1 (October 27, 2010).

147 Communication from the Commission, $\operatorname{COM}(2006) 819$ final, supra note 107, at 2.

148 See European Commission, supra note 146, at 1.

149 See Dempsey, supra note 27, at 312; H. Stevens, Transport Policy in the European Union, Basingstoke, at 1 (2004); Balfour, supra note 26, at 443; R. Bieber, F. Maiani, M. Delaloye, Droit européen des transports, Genève, Bruxelles, Paris, at 3 (2006), which state that "[l]a mobilité est une condition fondamentale de l'existence de l'homme", and "assure la survie, l'accès aux ressources nécessaires, la satisfaction des besoins physiques de l'homme." See also Communication from the Commission $\operatorname{COM}(2011) 415$ final, supra note 119, at 1; Communication from the Commission to the Council and to the European Parliament, on the application of Regulation 261/2004 establishing common rules on compensation and assistance to passengers in the event denied boarding and of cancellation or long delay of flights, $\operatorname{COM}(2011) 174$ final, at 1 (April 11, 2011), according to which "[t]ravelling is a necessary prerequisite for the exercise of the freedom of movement."

As regard the role played by the Common Transport Policy see Dempsey, Aerial Dogfights, supra note 35, at $638 \mathrm{ff}$.

150 See Communication from the Commission, $\operatorname{COM}(2011) 174$ final, supra note 147, at 2.1, according to which " $[\mathrm{t}]$ ravelling by air is no longer perceived as a luxury, but has become a necessity to meet business needs and a self-evident right for European citizens." 


\subsection{Drawbacks.}

\subsubsection{Obstacles to further development of liberalization policies within the EU} and with its third country partners.

Air transport liberalization policies have to take into account drawbacks stemming from their implementation.

Firstly, the quality of the air transport growth is negatively affected in some respects, such as: delays due to airspace congestion; crowded airports and insufficient contingency planning in case of severe bad weather; stricter security measures; bigger airports with longer distances which imply, for passengers, risks in retrieving luggage and missing flights; and some commercial practices for air carriers which may negatively impact upon passengers (such as the so-called "no show policy" or practices linked to the mishandling of luggage that show loopholes and deficiencies in the application of current legislation). ${ }^{151}$

Secondly, with specific regard to the recent EU-US liberalization initiatives (despite the fact that following considerations can be generalized, that is, extended to many other Open Skies agreements), airlines operating on EU-US services will face additional competition and pressure costs. ${ }^{152}$

By liberalization policies, there has been a significant increase in the number of low cost airlines. Indeed, the EU currently has twenty low-cost carriers representing $40,2 \%$ of the internal EU market. In 1990, there were nine only: see EU, MEMO/11/469, supra note 104, at 4. See also M.E. Levine, Airport Congestion: When Theory Meets Reality, 26 Yale Journal on Regulation, 58, at 59 (2009), who states that air transport deregulation "is one of the most successful policy changes in the last fifty years", as "flying from a luxury to an accessible necessity, bringing families and the country together, fostering economic growth, and living ordinary people access to a wealth of experiences previously reserved for the uppermiddle class".

As " $[t]$ oday, the universe is global", some Authors point out that "[b]y shrinking the planet, aviation is a principal means of intermingling and integrating disparate economies and cultures, stimulating social and cultures cross-fertilization, economic growth and diversity in an increasingly inter-dependent global environment": see P.S. Dempsey - L.E. Gesell, Airline Management, supra note 6, at 2. See also Havel and Sanchez, supra note 30, at 4; K.G. Debbage, Airport runway slots. Limits to grow, in 29 Annals of Tourism Research, 933 ff. (2002); D. Nikomborirak, Strategic Directions for ASEAN Airlines in a Globalizing World. Competition and Consumer Protection Policy. Final Report, at 29 (October 2005), who states that "[a]ir transport liberalization and the emergence of low cost airlines have made air travel much more affordable"; IATA, The Economic Impact of Air Service Liberalization, at 3 (May 30, 2006); ICAO, A36-WP/16, supra note 32, at paragraph 3.6; ICAO, A37-WP/5 EC/1, supra note 6, at paragraph 3.3; J.K. Brueckner and E. Pels, Institutions, Regulation, and the Evolution of European Air Transport, Working Paper, VU University Amsterdam, Faculty of Economics, Business Administration and Econometrics, Serie research Memoranda, No. 10, at 1 (June 2003).

151 Communication from the Commission, $\operatorname{COM}(2011) 174$ final, supra note 147, at 2.1.

152 Booz, Allen, Hamilton, supra note 142, at iii. 
Thirdly, States lose control on air transportation as a consequence of the passage from the reciprocal designation of aircraft between two States (according to the old bilateral system) to the EU-US Open Skies agreement. ${ }^{153}$

Fourthly, it is likely that there will be a significant increase of airport congestion due to the growth in the number of air passengers, which in turn will generate increased pollution.

Fifthly, the re-regulation process, consequent to liberalization policies, could represent a drawback giving rise to over-regulation, excess of bureaucracy, lack of transparency and other similar phenomena belonging to the past when the main actors in the field of air transport were national governments within a monopolistic policy. In that sense, regionalism could "weight" (or even eliminate) liberalization process benefits.

Sixthly, the potential effects of the EU-US Agreement (which sets down no provision on the subject of slot allocation ${ }^{154}$ ) could come to naught because of the lack of slots in most EU international airports (including those long under Open Skies agreements) which are allocated according to Regulation 95/93 whose cornerstone is the grandfather's rule. ${ }^{155}$ In contrast, in the US there are no explicit slot allocations ${ }^{156}$ (apart from at Washington National ${ }^{157}$ ) since the High Density Rule was phased out. ${ }^{158}$

Furthermore, the US protectionist stance on airline ownership makes it difficult to envision further steps toward a more liberalized market due to the fact

153 Within the European Union system, Member States cede powers of regulation and enforcement to supranational institutions.

154 Humphreys and Morrell, supra note 142, at 77; Balfour, supra note 26, at 456.

155 In the EU slot allocation system it does not exist a buy-sell slot rule, like that enacted in the US in 1986. Notwithstanding, a "grey market" of slots is well-established, above all in the UK. Moreover, a recent Communication issued by the European Commission (Communication from the Commission to the European Parliament, the Council, the European Economic and Social Committee of the Regions, on the application of Regulation (EEC) No. 95/93 of 18 January 1993 on common rules for the allocation of slots at Community airports, as amended, $\operatorname{COM}(2008), 227$ final, $\$ 5$ (April 30, 2008)) introduces, ex facto, a secondary trading of slots. As a result, US airlines can currently buy slots allocated freely at EU congested airports. In that way, the lack of slots is, at least partly, reduced. See Humphreys and Morrell, supra note 142, at 77.

156 Button, supra note 1 , at 69 .

157 Steer, Davies, Gleave, Impact assessment of revisions to Regulation 95/93. Final report (sections 1-12), March 2011, 125.

158 On April 5, 2000, was promulgated the Wendell H. Ford Aviation Investment and Reform Act for the $21^{\text {st }}$ Century (FAIR-21), which set down the elimination of slot restrictions at Chicago O'Hare by July 1, 2002, and at New York LaGuardia and Kennedy by January 1 , 2007. As a consequence, slot restrictions in those High Density Airports were statutorily terminated: see Havel, supra note 3, at 196, especially note No. 399; Levine, supra note 150, at 61; P.S. Dempsey, Airport landing slots: Barriers to Entry and Impediments to Competition, 26 Air \& Space Law, 39 (February 2001); P.S. Dempsey and L.E. Gesell, Air Commerce and the Law, Coast Aire, Chandler, 502 (2004); Button, supra note 1, at 69. 
that in the 2010 US-EU Protocol, only a limited compromise on investment rights was found (see Protocol, Article 6, paragraph 2).

Last but not least, several differences exist between the EU and the US. Clear examples of these differences exist within Labour and Environment laws.

With specific regard to EU-Russia relations, although a new strategy for air transportation towards liberalization and privatization is under way, the Russian State continues to play an influential role in the aviation industry. For this reason the aviation market in Russia is still characterized by a restrictive approach, and market access is limited. ${ }^{159}$ Moreover, the longstanding problem of Siberian overflight payments has yet to be resolved. This issue is of major importance for European air carriers, as it affects services between Europe and the growing and lucrative markets in the Far East, particularly China. ${ }^{\mathbf{1 6 0}}$

More generally, relations between the EU and Russia are very fragmented as Member States still act individually, thus they are neither able to bring bilateral agreements into conformity with EU law, nor solve crucial issues such as Siberian overflight payments, nor achieve significant progress in market access. ${ }^{161}$

\subsubsection{Safety and security.}

The European Commission is aware that air transportation is both a target and an instrument of terrorism. Following the events of September 11, 2001, the EU reacted swiftly with legislation and quality control inspection regimes to enhance security in aviation transportation. ${ }^{162}$

An Open Aviation Area, like that established between the EU and the US, needs a regulatory convergence and harmonization of air transportation standards in safety, security, and the environment. ${ }^{163}$ Indeed, the 2007 EU-US Agreement itself envisages cooperation in several areas, among which are safety and security. ${ }^{164}$ In 2007, the European Commission drew up a Proposal to strengthen cooperation between the EU and the US in the field of safety. ${ }^{165}$

159 Communication from the Commission, supra note 97, at 1 and 4.2.

160 Communication from the Commission, supra note 97, at 1.

161 Communication from the Commission, supra note 97, at 1.

162 Communication from the Commission, supra note 120, at 4.4. Moreover the Commission observes that a "level playing field needs to be stimulated where the cost of security measures is likely to distort competition. [...] Careful consideration needs to be given to international cooperation in order to improve worldwide standards and avoid unnecessary and costly duplication of controls" (ibidem). As an "action", the Commission envisages, inter alia, to strengthen the functioning of the European safety agency (EASA) and gradually extend its safety-related tasks.

163 Booz, Allen, Hamilton, supra note 142, at iii. See also ICAO, Declaration of global principles for the liberalization of international air transport, Montreal (March 2003).

164 Balfour, supra note 26, at 457; Masutti, supra note 3, at 161.

165 European Commission, Proposal for a Council Decision on the Signature of an Agreement between the European Community and the United States of America on the cooperation in 
Much more complicated are the safety and security issues within the aviation relations between the EU and Russia, due to the fragmented relations between them. Indeed, it has been pointed out that the different approaches to safety and noise are a constant source of potential misunderstandings in aviation relations. ${ }^{166}$ The future agreement between the EU and Russia should establish a close cooperation to ensure that the highest international security standards could be met. To this end, joint mechanisms and procedures could also be developed under the agreement. ${ }^{167}$

As ICAO pointed out in 2003, safety (and security) is one of the most important goals in the field of air transport, and it has to be reached irrespective of any change in economic regulatory arrangements. ${ }^{168}$ In light of this, the European Commission states that the increased competitive pressure and greater freedom to invest internationally that might result from agreements should never lead to compromise on global standards. ${ }^{169}$

In EU law, significant progress has been made towards improving aviation safety, including the introduction of a blacklist of unsafe airlines, which has been recently updated. ${ }^{170} \mathrm{~A}$ broad set of common safety standards is enforced with the help of the dedicated European aviation agency, namely the EASA. ${ }^{171}$ In 2008, Regulation 300 of 2008 was adopted. ${ }^{172}$ It establishes common rules to protect civil aviation against acts of unlawful interference that jeopardize the security of civil aviation (Article 1).

In this context, safety standards, which are developed and set internationally by ICAO and which are adhered to by all nations under the EU-US Agreement, remain essential, even though some commentator points out that there is no

the regulation of civil aviation safety, $\operatorname{COM}(2007) 325$, final (June 14, 2007).

166 Communication from the Commission, supra note 97, at 1.

167 Communication from the Commission, supra note 97, at 4.5.

168 ICAO, supra note 162.

169 Communication from the Commission, supra note 50, at 54-62.

170 EU, Press Releases, Aviation: Commission updates the EU list of air carriers subject to an operating ban, IP/11/1375 (November 21, 2011).

171 Communication from the Commission, supra note 120, at 4.3. The EASA is the centerpiece of the European Union's strategy for aviation safety. Its mission is to promote the highest common standards of safety and environmental protection in civil aviation. The Agency monitors the implementation of standards through inspections in the Member States and provides the necessary technical expertise, training and research. It works in close cooperation with the national authorities (which continue to carry out many tasks, such as certification of individual aircraft or licensing of pilots). In general, on the EASA see V. Randazzo, Alcuni profili problematici relativi all'attribuzione di funzioni all'Agenzia europea per la sicurezza aerea, in Dir. Un. Eur., at 847-867 (2004).

172 Regulation (EC) No. 300/2008 of the European Parliament and of the Council of 11 March 2008, on common rules in the field of civil aviation security and repealing Regulation (EC) No. $2320 / 2002$. 
evidence that the increase in Open Skies style arrangements across the globe has in any way impacted adversely on air transport safety. ${ }^{173}$

\section{Conclusions.}

4.1 Liberalization, re-regulation and cooperation between the EU (and other regional organizations) and international organizations.

Article 80 of the 1957 EEC Treaty of Rome specified that the provisions on common market policy contained in Title IV of the Treaty were applicable to the air transport sector, but the Council did not enact these legislative measures until the end of the 1980s. Liberalization policies in the EU were implemented gradually, mostly due to factors that were external to the European Economic Community. The main factor was the 1978 US deregulation.

The EU air transport liberalization has produced positive and negative results. Despite the fact that this new policy has yielded some disadvantages, we have to take into account the important benefits for all the Member States.

The EU liberalization policies implied that EU institutions were making precise political choices. These institutions founded the policies on a balance of interests, which always occurs when reforms are implemented. In the air transport field it was necessary to open up the market to make freedoms (e.g., of movement) and rights truly exercisable, but it was also necessary to keep certain standards (e.g., those concerning safety and security) unchanged.

Consequently, it was not a surprise that liberalization policies brought about a new regulatory Era based on, inter alia, competition rules. These re-regulatory policies have been driving all the recent experiences in the field of air transport liberalization (at national, regional and international levels).

If regional contributions are needed to foster and consolidate liberalization initiatives in the air transport sector, this adds a third level of regulation to national and international. This third level brings about an over-regulation and contributes marginally to solving the problem of "over-fragmentation" of air transport worldwide ${ }^{174}$, as has been backed up by some authors. ${ }^{175}$

This international fragmentation should be addressed and regulated by international organizations specialized in the air transport field, such as ICAO, whose mandate covers a broad range of actions, including those concerning economic

173 Button, supra note 1 , at 70-71.

174 The phenomenon of fragmentation in air transport has many implications, among which some are related to European airspace. The recent Regulation EU No. 176/2011, on the information to be provided before the establishment and modification of a functional airspace block, issued by the Commission on February 24, 2011, will help to solve this fragmentation, and will give an important contribute to the creation of the Single European Sky.

175 Lelieur, supra note 9, at 117. 
regulation (and so, inter alia, competition issues: see Article 44 of the Chicago Convention). Only such organizations can assure that air transport policies comply with safety and security standards as set out internationally by ICAO.

Furthermore, the political role of ICAO would be encouraged with some issues that are currently involving the EU. Indeed, one of the thorniest issues that have to be solved in the foreseeable future is the aviation relations between the EU and Russia. In this respect, a comprehensive EU-Russia air transport agreement would aim to bring about the broadening of aviation relations and establish a framework in which both the industry and users can benefit from improved market conditions, a stable and consistent legal environment between the two markets, and mechanisms through which differences are avoided or resolved. ${ }^{176}$

As concerns the Siberian overflight payments issue, given that thus far the bilateral negotiations between the EU and the Russian Federation have not yielded the necessary results to overcome this issue, a parallel action under the ICAO umbrella may be pursued in order to lead the Russian Federation to abide by Article 15 of the Chicago Convention. ${ }^{177}$

In any case, it would be necessary that the EU would be given the status of a Party of ICAO, rather than its current status of an "observer." In other words, the EU should act with one voice only. Actually, this problem is directly linked to the legal nature of the European Union, which so far is not yet a "State" from a legal point of view.

The importance of a stronger cooperation between the EU and ICAO is shown by the recent Memorandum of Cooperation, which has just been signed between the Commission and ICAO. ${ }^{178}$

The prominent role of ICAO would not entail any exclusion in terms of international cooperation among supranational or international organizations, such as the WTO. ${ }^{179}$ Indeed, it has been argued that these international Organizations (ICAO and WTO) are not in competition with each other because their roles are different. ${ }^{180}$ Accordingly, the current and future (new) legal order in internation-

176 Communication from the Commission, supra note 97, at 1.

177 See Communication from the Commission, supra note 97, at 4.4.

178 According to the MoC, a stronger European involvement in the ICAO activities will be implemented, above all in the fields of safety, security, environment and traffic management: see EU, Press Releases, IP/11/540, supra note 101.

179 See A. Mencik Von Zebinsky, The General Agreement on Trade in Services: Its Implications for Air Transport, 18 Annals of Air and Space Law, at 391 (1993). The idea of a closer cooperation between ICAO and WTO has been backed up by ICAO itself, as it declared itself to be willing 'to share its expertise and participate actively in the WTO's future work on the classification of international air transport activities for the purpose of negotiation or application of the GATS to air transport': see ICAO, supra note 17, at 4.1.

180 Lelieur, supra note 9, at 131, who argues that ICAO, WTO and OECD cooperate in order to improve and accelerate the liberalization process. They provide new ideas and advocate debates as concerns complex issues regarding air transport liberalizations. See also R. 
al air transport should be based on the cooperation at plurilateral level, which is considered an alternative to regionalism and multilateralism. ${ }^{181}$ This does not mean that regional fora are less important in setting and intensifying business relations and promoting economic growth between regional organizations, as recent initiatives have pointed out. ${ }^{182}$ We believe that regional organizations should operate under supra-national and supra-regional organizations, which are able to harmonize and set provisions regardless of territorial boundaries.

ICAO is the "natural" international organization that deals with aviation issues. In spite of this, as we have seen above, ICAO is not in competition with other international organizations that address aviation matters; rather, a stronger cooperation with other international organizations is encouraged also by the ICAO Council itself in order to address issues of common interest in the field of air transport. ${ }^{183}$

\subsection{Final remarks.}

In conclusion, the pursuit of normalization of the international aviation industry can be reached providing that a stronger cooperation between international and regional actors will be implemented. This cooperation should be enacted under the ICAO umbrella, which is the only specialized international organization able to cover (almost) any international air transport matter. In that way, the current process of re-regulation of air transport as a consequence of the

Ebdon, A Consideration of GATS and of its Compatibility with the Existing regime for Air Transport, 20 Air \& Space Law, 71, at 75 (1995), who states that the Chicago-based system of air transport regulation and the GATS can co-exist.

181 Wassembergh, supra note 21, at 274-276. See also S. Espínola, Global Civil Aviation Governance, 27 Annals of Air and Space Law, 313, at 315-317 (2002); R. Abeyratne, Would competition in commercial aviation ever fit into the World Trade Organization?, 61 Journal of Air Law and Commerce, at 837 (1995-1996).

182 We refer to the recent first EU-ASEAN Business Summit held in Jakarta in May 2011 (on which see EU, Press Releases, $1^{\text {st }}$ EU-ASEAN Business Summit in Jakarta set to strengthen regional trade and investment, IP/11/520 (May 2, 2011). On this Summit see also the speech given by the European Commissioner for trade, Karel De Gucht, Closing Remarks to the first ever ASEAN-EU Business Summit, Speech/11/309, Jakarta, May 5, 2011), and to the strategic partnership between EU and Africa (on which see EU, The Joint Africa-EU Strategy, MEMO/11/351, May 27, 2011). Moreover, as concerns regional integration, see EU, Press Releases, An important step towards regional integration: EU and Central America initial Association Agreement, IP/11/336 (March 22, 2011).

183 ICAO, Economic Commission, Developments in International Air Transport Regulation and Liberalization, A37-WP/5 EC/1, Presented by the Council of ICAO to the ICAO Assembly's $37^{\text {th }}$ Session, at 4.2 (June 18, 2010). See also, ICAO, ICAO'S role in facilitating air transport liberalization, Presented by the ICAO Secretariat, at 4.2 (November 28, 2000); ICAO, Executive Committee, Cooperation with regional organizations and regional civil aviation bodies, Presented by the Council of ICAO to the ICAO Assembly's $37^{\text {th }}$ Session, A37-WP/28 EX/11 (June 17, 2010). See also L. Weber, International Civil Aviation Organization: An Introduction, Alphen aan den Rijn, at 49-52 (2007). 
implementation of the $\mathrm{EU}$ (and other regional organizations) liberalization policies may be completed. 